\title{
ANALISIS PENGATURAN POSISI CONTROL RODS PADA KONSEP REAKTOR DAYA EKSPERIMENTAL INDONESIA PASCA REACTOR SCRAM
}

\section{POST REACTOR SCRAM CONTROL RODS POSITION ADJUSTMENT ANALYSIS FOR THE INDONESIAN EXPERIMENTAL POWER REACTOR CONCEPT}

\author{
Syarip ${ }^{1}$, Khoirul Anam², Dwi Priyantoro² \\ 1 Pusat Sains \& Teknologi Akselerator, BATAN \\ Jl. Babarsari POB 6101 ykbb, Yogyakarta 55281 \\ ${ }^{2}$ Sekolah Tinggi Teknologi Nuklir, BATAN \\ Jl. Babarsari Yogyakarta \\ syarip@batan.go.id.
}

Diterima 16 Agustus 2016), diterima dalam bentuk perbaikan 11 Oktober 2016, disetujui 24 Oktober 2016

\begin{abstract}
ABSTRAK
ANALISIS PENGATURAN POSISI CONTROL RODS PADA KONSEP REAKTOR DAYA EKSPERIMENTAL INDONESIA PASCA REACTOR SCRAM. Telah dilakukan analisis simulasi pengaturan posisi batang-batang kendali untuk melanjutkan operasi reaktor daya eksperimental (RDE) paska scram setelah beroperasi pada periode waktu tertentu. Pengendalian reaktivitas pada reaktor RDE yang akan dibangun di Indonesia dengan rujukan high temperature gas reactor (HTR) 10 MWt, dilakukan dengan 10 pasang batang-batang kendali atau control rod (CR). Apabila terrjadi kondisi abnormal maka CR secara otomatis akan jatuh tersisip ke dalam reflektor reaktor sehingga reaktor scram dan berada pada kondisi subkritis. Untuk melanjutkan operasi reaktor pasca scram diperlukan analisis terkait pengaruh reaktivitas negatif dari Xenon dan suhu. Pada makalah ini disajikan hasil simulasi yang dilakukan untuk penentuan posisi CR paling optimum untuk melanjutkan operasi reaktor, menggunakan simulator PCTRAN-HTR. Simulasi dilakukan pada variasi 70\%, 85\% dan 100\% dari tingkat daya penuh dan dengan variasi waktu operasi 50 s, 10.000 s, dan 20.000 s di mana setelah reaktor beroperasi pada tingkat-tingkat daya dan waktu operasi tersebut reaktor mengalami scram. Untuk melanjutkan operasi lagi maka CR harus dinaikkan lagi dan diatur ke posisi tertentu sampai reaktor mencapai kondisi kritis lagi pada tingkat daya nominal tersebut. Hasil yang telah diperoleh menunjukkan bahwa dengan posisi CR naik $52 \%$ sudah bisa menghasilkan kondisi kritis dan mampu mengatasi reaktivitas negatif peracunan xenon maupun suhu.
\end{abstract}

Kata kunci: RDE, HTR, operasi reaktor, batang kendali, reaktivitas, scram

\section{ABSTRACT}

POST REACTOR SCRAM CONTROL RODS POSITION ADJUSTMENT ANALYSIS FOR THE INDONESIAN EXPERIMENTAL POWER REACTOR CONCEPT. Analytical study using PC-based simulator has been carried out on control rods position adjustment of the Indonesian experimental power reactor concept or reaktor daya ekperimental (RDE) in a post reactor scram to continue operation after a certain operation period. Reactivity control of the RDE uses 10 pairs of control rods (CRs), which is based on that applied in the high temperature gas reactor (HTR) $10 \mathrm{MW}(t)$. If an abnormal operating condition occurs, these control rods automatically dropped to the reflector that bring the reactor into a scram and subcritical condition. To continue reactor operation after a period of time, the CRs should be withdrawn to achieve recriticality. Prior to any CRs withdrawal, an analysis of negative reactivity effects of Xenon (poissoning) and fuel temperature coefficient should be done. Simulations using PCTRAN-HTR simulator to determine the optimum CRs positions in achieving reactor criticality for continuation of reactor operation is presented in this paper. The simulations were conducted by varying the reactor power levels at $70 \%, 85 \%$ and $100 \%$ of full power, respectively. The reactor operation time was varied at 50s, $10.000 \mathrm{~s}$, and $20.000 \mathrm{~s}$ prior to the reactor scram. Adjustment of CRs position should be done to continue reactor operation at those nominal power levels by withdrawing the CRs to the proper positions. The simulation results show that recriticality can be achieverd by whitdrawing the CRs $52 \%$ of farther and the negative reactivity from xenon poisoning and temperature could be overcome.

Keywords : RDE, HTR, reactor operation, control rod, reactivity, scram. 
Jurnal Iptek Nuklir Ganendra

Ganendra Journal of Nuclear Science and Technology

Vol. 19, No. 2, Juli $2016: 83-93$

\section{PENDAHULUAN}

$\mathrm{R}^{\mathrm{s}}$ aktor daya eksperimental (RDE) yang akan dibangun di Indonesia dengan daya nominal $10 \mathrm{MWt}$ adalah jenis High Temperature Gas-Cooled Reactor (HTGR/HTR), dan beberapa penelitian terkait analisis keselamatan RDE telah dilakukan. Daya RDE merujuk pada High Temperature Reactor (HTR-10) yang saat ini sedang beroperasi di China dengan daya 10 MWth [1]. HTR-10 adalah jenis reaktor termal bersuhu tinggi termasuk reaktor nuklir generasi-4. HTR adalah reaktor nuklir bermoderator grafit, berbahan bakar kernel U235 dan berpendingin gas helium. Saat ini ada beberapa macam HTGR yang sedang beroperasi diantaranya High Temperature Test Reactor (HTTR) di Jepang dengan daya 30 MWth dan HTR-10 di China dengan daya 10 MWth [2]. Sebagai rujukan utama pada penelitian ini diambil HTR-10 China, karena jenis reaktor dan tingkat daya yang sama dengan RDE yang akan di bangun di Indonesia.

Penelitian ini merupakan sebagian dari program kegiatan penyusunan Simulator Hibrid Berbasis Reaktor Kartini Untuk Pelatihan Pengendalian RDE [3], yaitu bagian dari topik pelatihan pengendalian reaktor RDE. Tujuan dari simulator hybrid berbasis reaktor Kartini tersebut serupa dengan engineering simulation system (ESS), yang dikembangkan untuk pelatihan awal para operator reaktor HTR-PM (Cina) yang a.I. untuk verifikasi sistem kendali dan prosedur operasi reaktor tersebut $[4,5]$. HTGR (RDE) adalah reaktor inovatif dengan karakteristik yang menguntungkan dari sisi ekonomi, keselamatan, infrastruktur, proliferation resistance dan proteksi fisik, lingkungan dan limbah serta memiliki keselamatan bawaan (inherent safety) yang baik berupa kapasitas panas teras reaktor yang besar dan efek umpan balik reaktifitas negatif (negative reactivity feedback effect) yang bisa membuat reaktor tetap stabil ketika terjadi penarikan batang kendali (CR) secara tak wajar maupun karena kejadian mengancam lainnya. Kapasitas panas teras reaktor yang besar berarti reaktor ini memiliki kemampuan tinggi untuk mengumpulkan panas dan efek umpan balik reaktifitas negatif artinya kemampuan mengurangi reaksi fisi nuklir secara segera ketika terjadi peningkatan suhu teras reaktor yang berlebihan [4].

Pada pengoperasian RDE dengan rujukan HTR-10, kestabilan daya bisa dicapai dengan mengatur reaktivitas teras menggunakan $C R$. Dengan pengaturan $C R$, reaktor menghasilkan suhu keluaran yang sesuai/stabil sehingga tingkatan daya juga stabil. CR tersebut dimasukkan (disisipkan) ke blok reflektor atau ditarik (withdrawal) dari blok reflektor sesuai dengan tingkat kestabilan suhu maupun daya yang ditentukan. Selain itu, bila keadaan darurat CR juga digunakan untuk mematikan reaktor/scram dengan aman. Sistem scram ini mengandalkan gravitasi sebagai pendorongnya setelah terjadi hal-hal yang mengancam keselamatan reaktor di antaranya adalah panas berlebihan, daya listrik sistem keamanan itu sendiri tidak stabil atau terjadi kehilangan pasokan daya lisrik sebagaimana yang telah disimulasikan pada HTTR-30 MWt Jepang a.l. oleh Tochio dkk, Takeda dkk, dan Takamatsu dkk, $[6,7,8]$. Mereka melakukannya dengan cara manual shutdown sebagai simulasi kehilangan pasokan daya listrik (loss of off-site electrical power) dari salah satu kejadian operasi yang diantisipasi (anticipated operational occurences, AOO). Hal tersebut tentunya juga harus menjadi perhatian dalam pengembangan RDE di Indonesia mengingat di negara ini juga sering terjadi pemadaman daya listrik baik dalam waktu singkat maupun lama.

Gangguan penyedia daya listrik dapat mengakibatkan reaktor mengalami scram, sedangkan reaktor harus melanjutkan operasi, maka perlu pengaturan posisi batang-batang kendali sedemikian rupa sehingga reaktor dapat melanjutkan operasi dengan aman. Pengaturan (penarikan-penyisipan) posisi batang-batang kendali (CR) tersebut harus dilakukan sesuai dengan karakteristik HTR (RDE) itu sendiri yang memiliki kapasitas panas teras reaktor yang besar dan di sisi lain juga memiliki efek umpan balik reaktivitas negatif. Dengan demikian diharapkan penelitian ini bisa dijadikan acuan untuk pengoperasian reaktor RDE paska scram di mana daya minimal reaktor dapat dicapai kembali, dengan mempertimbangkan suhu sistem pendingin dan efek umpan balik reaktivitas teras.

\section{DESKRIPSI RINGKAS SISTEM REAKTOR HTR-10}

HTR-10 yang dijadikan rujukan RDE adalah jenis reaktor suhu tinggi tipe pebble-bed dengan pendingin gas helium dan bermoderator grafit. Sistem fluida HTR-10 terdiri dari sistem pendingin dengan fluida berupa gas helium sebagai pendingin teras reaktor dan sistem pendingin kavitas reaktor (reactor cavity cooling system, RCCS) dengan fluida berupa air dalam pipa sebagai pendingin ruang udara antar bejana tekan reaktor (reactor pressure vessel, RPV) dan dinding beton. 

(Syarip, dkk.)

Teras aktif HTR-10 berbentuk silinder seluruhnya terbuat dari bahan grafit dan berbentuk kerucut pada dasar untuk unloading elemen bahan bakar. Reflektor grafit dan refelektor bata karbon terletak di sekitar teras pada sisi sebelah atas, samping dan bawah. Setelah masuk bejana tekan, aliran gas helium dingin turun melalui celah anular antara bejana teras dan RPV. Baru kemudian aliran gas Helium mengarah ke atas. Sebagian kecil helium dingin ini diharapkan akan melalui langsung tabung pengeluaran bahan bakar menuju teras yang panas. Sedangkan helium yang lain menuju sekitar struktur pendukung teras dan sebagian besar aliran gas ini masuk ke bagian kanal-kanal helium yang dingin di dalam sisi reflektor, dapat dilihat Gambar 1 [2,3]. Secara umum parameter operasi HTR-10 adalah: daya $10 \mathrm{MW}$, suhu outlet dari reaktor $700{ }^{\circ} \mathrm{C}$, suhu inlet ke reaktor $250^{\circ} \mathrm{C}$, laju alir dan tekanan pendingin utama (helium) adalah 4,32 kg/detik dan tekanannya $3 \mathrm{Mpa}[8,9]$.

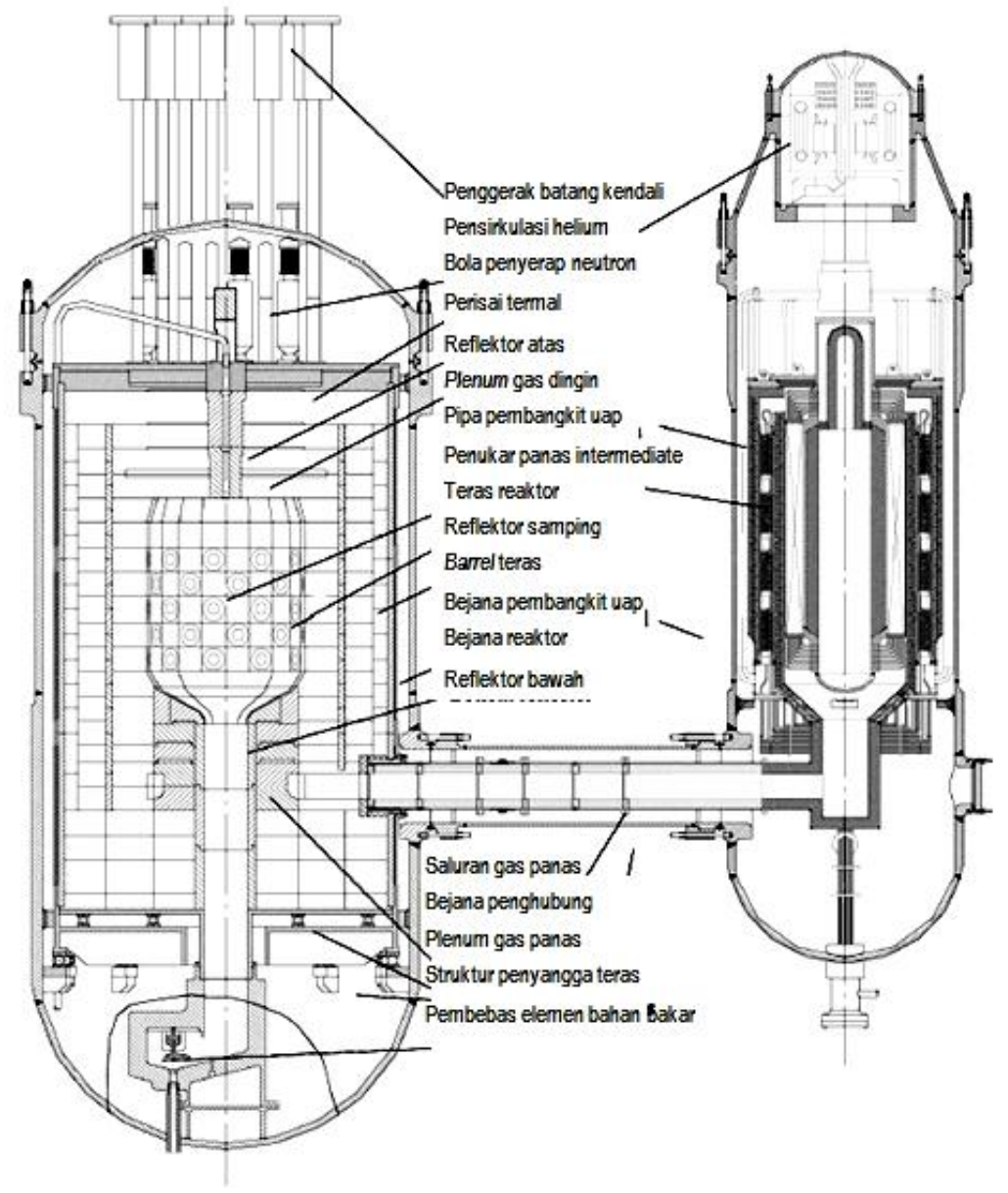

Gambar 1. Tampang lintang vertikal sistem utama reaktor suhu tinggi HTR-10 [3].

\section{Sistem Batang Kendali}

Gambar 2 memperlihatkan teras reaktor HTR-10 yang berisi kernel bahan bakar dilingkupi oleh reflektor dan batang-batang kendali. Batang kendali pada HTR-10 berjumlah 10 buah dan dilengkapi dengan bola-bola kecil penyerap neutron yang berjumlah 7 kanal, dengan struktur seperti dilukiskan pada Gambar 3. Batangbatang kendali dan bola-bola penyerap neutron semuanya diletakkan di dalam reflektor samping dengan kondisi masing-masing sebagai berikut:

- bahan penyerap neutron adalah boron karbida $\left(\mathrm{B}_{4} \mathrm{C}\right)$

- setiap bantang kendali mengandung 5 bagian $\mathrm{B}_{4} \mathrm{C}$ melingkar yang dilingkupi (sleeve) antara bagian dalam dan luar dengan bahan stainless steel (SS) yang terhubung bersama dengan metal sebagai joint.

- panjang tiap sambungan adalah $36 \mathrm{~mm}$

- bagian panjang akial (Gambar 3) dengan deskripsi material sebagai berikut: - 45/487/36/487/36/487/36/487/36/487/23 
- $\mathrm{SS} / \mathrm{B}_{4} \mathrm{C} / \mathrm{SS} / \mathrm{B}_{4} \mathrm{C} / \mathrm{SS} / \mathrm{B}_{4} \mathrm{C} / \mathrm{SS} / \mathrm{B}_{4} \mathrm{C} / \mathrm{SS} / \mathrm{B}_{4} \mathrm{C} / \mathrm{SS}$,

- Deskripsi urutan daerah radial dan ketebalan dalam $\mathrm{mm}$ dari batang kendali adalah sebagai berikut $27,5 \mathrm{~mm}$ (void) $/ 2 \mathrm{~mm}$ (SS) $/ 0,5 \mathrm{~mm}$ (void) $/ 22,5 \mathrm{~mm}\left(\mathrm{~B}_{4} \mathrm{C}\right) / 0,5 \mathrm{~mm}$ (void) $/ 2 \mathrm{~mm}$ (SS).

- densitas $B_{4} C$ adalah $1,7 \mathrm{gr} / \mathrm{cm}^{3}$

- koordinat akial ujung terbawah saat batang kendali sepenuhnya terangkat : $119,2 \mathrm{~cm}$

- koordinat akial ujung terbawah saat batang kendali sepenuhnya tersisipkan : $394,2 \mathrm{~cm}$

- densitas SS 7,9 gr/cm ${ }^{3}$ (komposisi bahan Cr-18\%, Fe-68,1\%, Ni-10\%, Si-1\%, Mn-2\%, C-0,1\%, Ti-0,8\%)

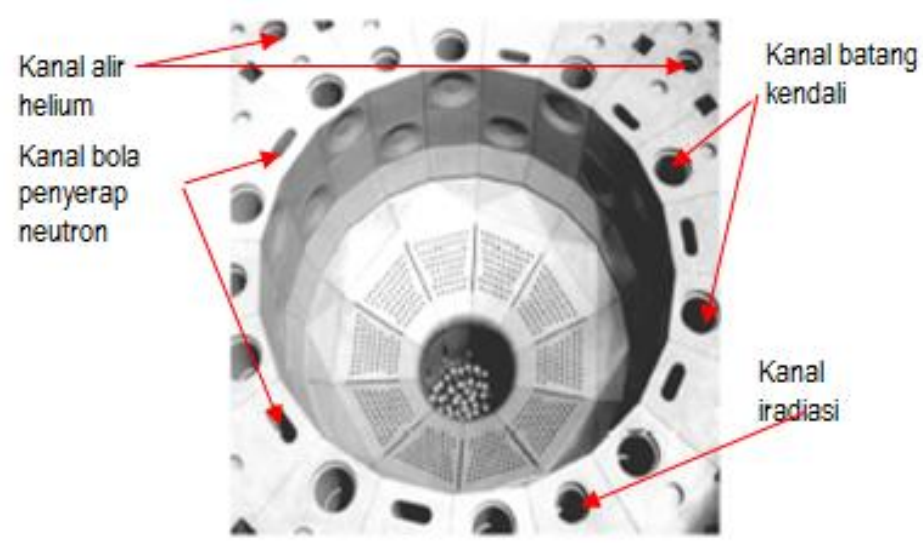

Gambar 2. Teras reaktor HTR-10 [2].

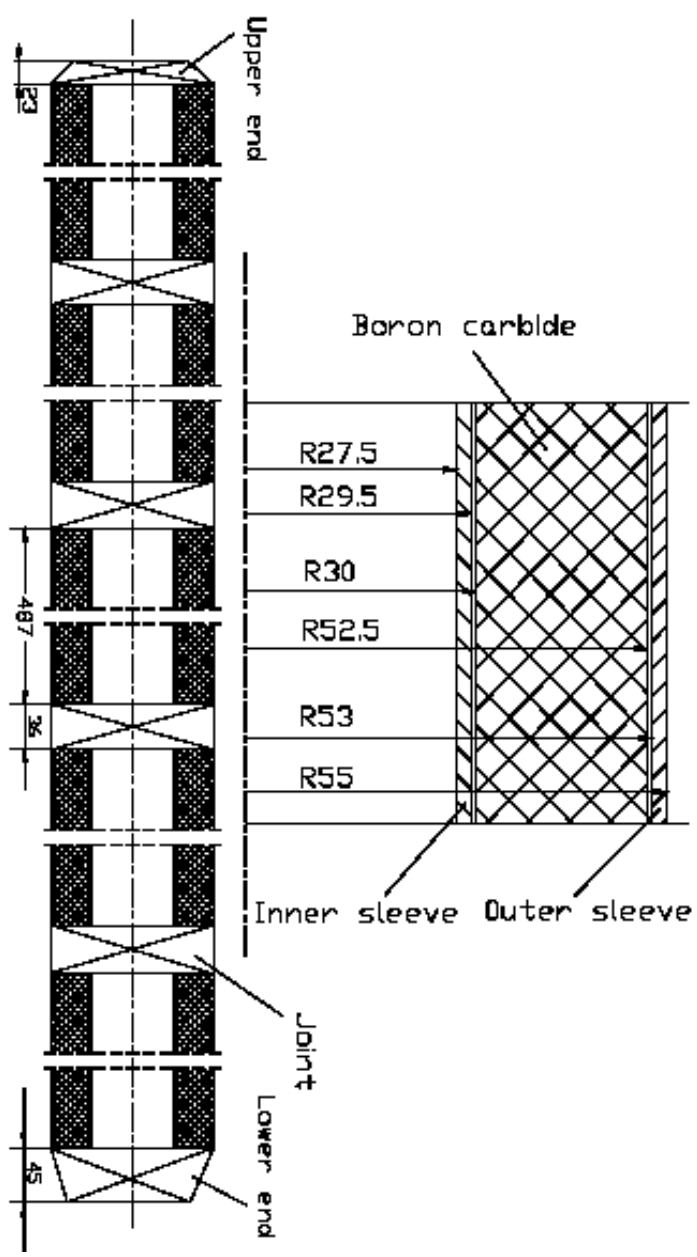

Gambar 3. Struktur batang kendali HTR-10 [2]. 
Reaktivitas masing-masing batang kendali terkalibrasi dengan metoda perioda pada lingkungan helium memiliki nilai reaktivitas yang sama yaitu $1,4 \times 10^{-2} \Delta \mathrm{k} / \mathrm{k}$ atau $1,9285 \$[3,9]$. Total reaktivitas batang kendali dalam reaktor nilai reaktivitas total batang kendali tersisipkan di dalam reflektor sepenuhnya adalah $19,85 \$$. Ada dua sistem pemadaman reaktor yaitu sistem batang kendali di mana kesepuluh batang kendali bisa jatuh bebas dan sistem tujuh kanal bola-bola kecil penyerap neutron, sistem tersebut semuanya dirancang berada di dalam reflektor samping. Kedua sistem tersebut dapat membawa reaktor ke kondisi padam-dingin. Spesifikasi teknis sistem batang kendali disajikan pada Tabel 1.

Tabel 1. Spesifikasi teknis sistem batang kendali HTR-10 [3].

\begin{tabular}{ll}
\hline Parameter & Nilai \\
\hline Ketinggian teras aktif rerata $(\mathrm{cm})$ & 197 \\
Jarak kanal batang kendali dari pusat teras reaktor $(\mathrm{cm})$ & 102,5 \\
Diameter kanal batang kendali $(\mathrm{cm})$ & 13 \\
Diameter dalam / luar penyerap $(\mathrm{cm})$ & $6,0 / 12,0$ \\
Material penyerap batang kendali & $\mathrm{B}_{4} \mathrm{C}$ \\
Densitas penyerap batang kendali $(\mathrm{g} / \mathrm{cm} 3)$ & 1,7 \\
Panjang efektif total penyerap batang kendali $(\mathrm{cm})$ & 220 \\
Kecepatan insersi normal batang kendali $(\mathrm{cm} / \mathrm{s})$ & 1,0 \\
Waktu insersi darurat batang kendali $(\mathrm{s})$ & 8 \\
Panjang total batang kendali $(\mathrm{cm})$ & 275 \\
Medium & $\mathrm{He}$ \\
Tekanan $(\mathrm{MPa})$ & 3,0 \\
\hline
\end{tabular}

\section{METODOLOGI}

\section{Bahan dan Alat}

Bahan yang digunakan pada penelitian ini berupa data-data HTR khususnya terkait sistem instrumentasi dan kendali, serta data operasi HTR-10 sebagai reaktor rujukan RDE. Alat yang digunakan pada penelitian ini adalah komputer dan perangkat lunak komputer PCTRAN-HTR [11].

\section{TATA KERJA}

Skenario simulasi penarikan CR pada HTR menggunakan simulator PCTRAN-HTR dilakukan dengan variasi daya $70 \%, 85 \%$ dan $100 \%$ dari daya nominal $10 \mathrm{MWt}$ dengan variasi waktu operasi 50 detik, 10 ribu detik, dan 20 ribu detik sebelum scram terjadi. PCTRAN-HTR adalah perangkat lunak komputer yang dibuat oleh Micro-Simulation Technology (MST) dengan tujuan mensimulasikan reaktor jenis HTR dengan daya nominal 200 MWt [11]. Untuk beroperasi pada daya $10 \mathrm{MWt}$ maka perlu dibuat 'initial condition' khusus di mana parameterparameternya disesuaikan dengan reaktor rujukan yaitu HTR-10. Contoh tampilan PCTRAN-HTR ditunjukkan pada Gambar 4. Diagram alir proses/ langkah simulasi dilukiskan pada Gambar 5.

Langkah simulasi diawali dengan mengoperasikan reaktor sampai reaktor sudah dalam kondisi daya konstan (status POWER) dan semua kondisi normal kemudian terjadi scram karena pasokan daya listrik ke sistem CR terputus beberapa saat sehingga CR jatuh. Untuk melanjutkan lagi perlu memperhatikan reaktivitas yang negatif terutama $\mathrm{Xe}^{135}$ yang memiliki nilai rektivitas negatif paling tinggi setelah 11,5 jam setelah reaktor scram. Setelah scram, maka status operasi reaktor adalah start (S) dan dilakukan penarikan CR pada posisi tertentu dengan kecepatan $6 \mathrm{~mm} / \mathrm{s}$ hingga teras menghasilkan fluks neutron yang cukup untuk mencapai daya reaktor sampai dengan $30 \%$ daya penuh. Kemudian status operasi reaktor diganti power $(\mathrm{P})$ dan terus dinaikkan hingga posisi daya menjadi steady state dan reaktivitas $\mathrm{Xe}^{135}$ mencapai kesetimbangan (dalam grafik terlihat menjadi datar). 


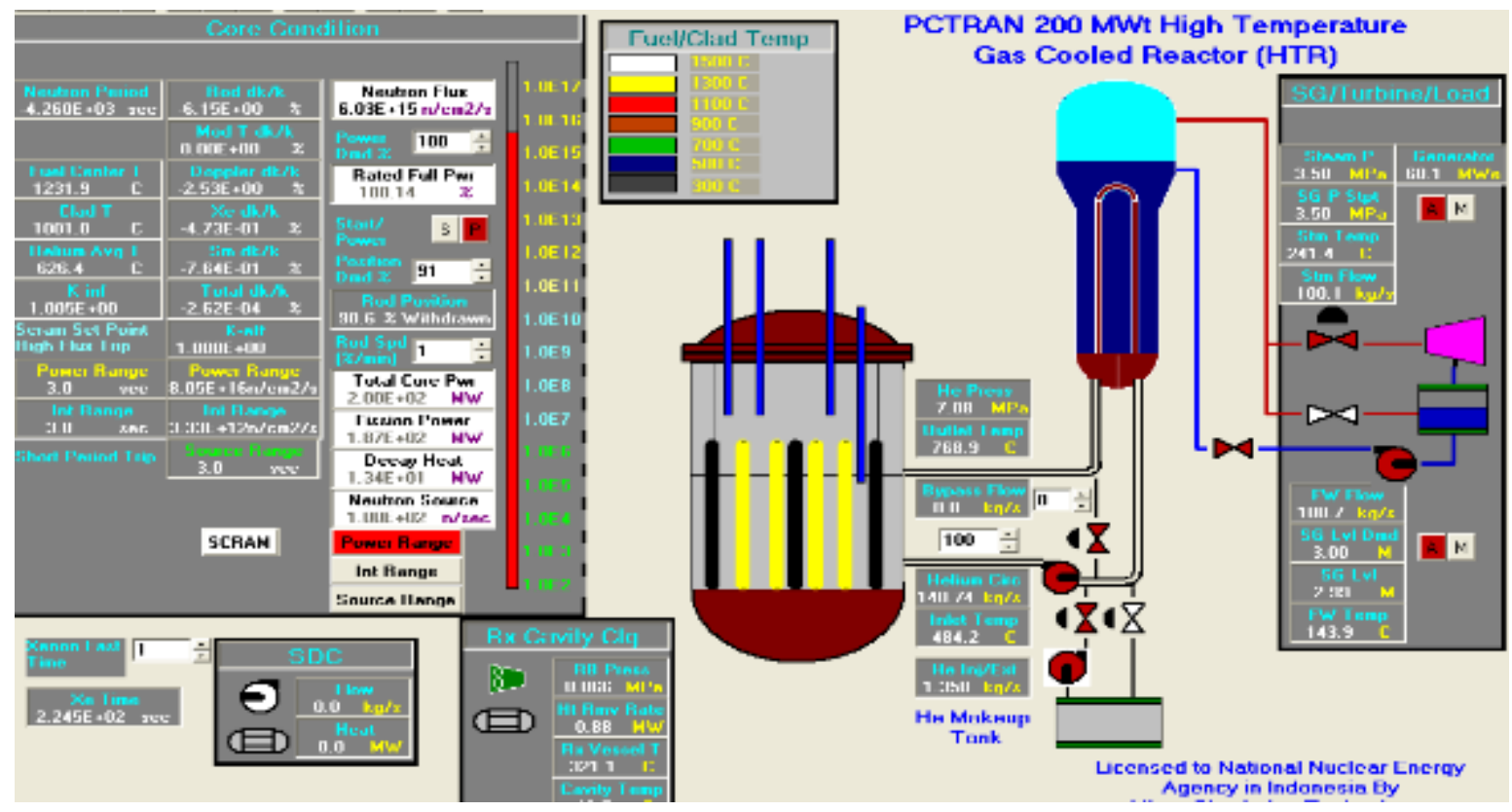

Gambar 4. Tampilan PCTRAN-HTR [11].

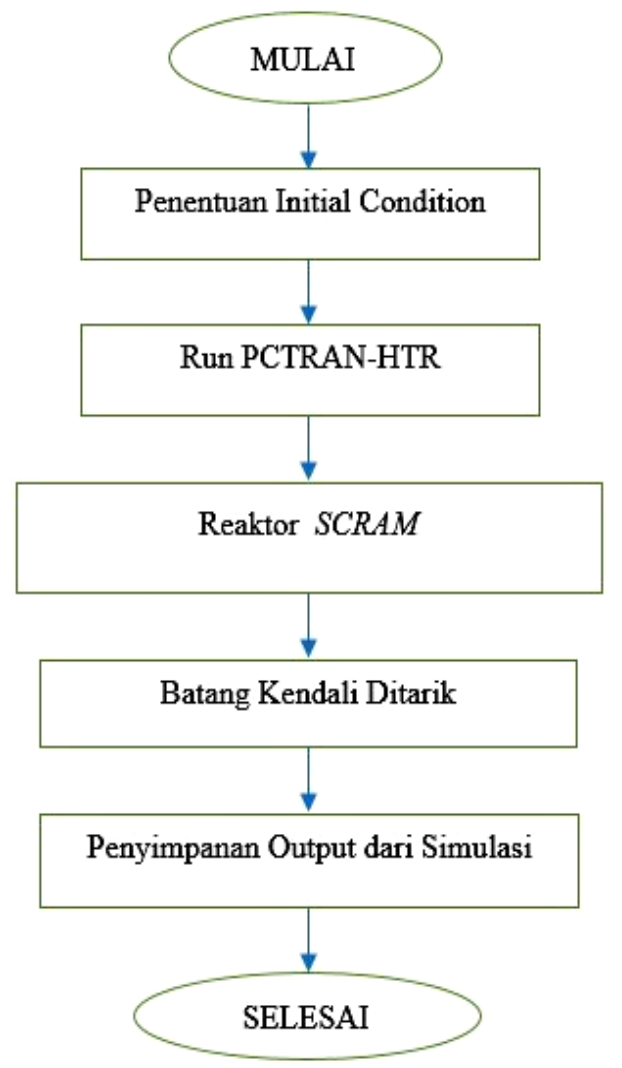

Gambar 5. Diagram alir proses simulasi.

\section{HASIL DAN PEMBAHASAN}

Simulasi penentuan posisi batang kendali paska reaktor scram dilakukan dengan variasi daya dan waktu operasi RDE sebelum SCRAM yaitu daya reaktor divariasi dari $70 \%$, 85\% dan $100 \%$ dari daya nominal $10 \mathrm{MWt}$, 

(Syarip, dkk.)

dan dengan variasi waktu operasi reaktor 50 detik, 10 ribu detik, dan 20 ribu detik. Variasi tingkat daya dan waktu operasi dilakukan karena reaktivitas negatif xenon sangat dipengaruhi oleh tingkat daya reaktor dan lama waktu operasi sebelum terjadinya scram. Berdasarkan hasil simulasi untuk tingkat daya $70 \%$ menunjukkan hasil yang masih sangat aman sedangkan pada tingkat daya 100\% sudah melampaui batas kondisi operasi yang ditentukan. Oleh karena itu pada pembahasan ini dibahas lebih rinci hasil simulasi pada tingkat daya $85 \%$ dari daya nominal sebelum reaktor scram. Hasil perhitungan simulasi pembentukan $\mathrm{Xe}^{135}$ di dalam teras RDE ditunjukkan pada Gambar 6 di mana puncak reaktivitas negatif 1,17\% dk/k setelah reaktor scram dari daya penuh. Selanjutnya untuk penarikan CR, kondisi xenon harus turun terlebih dahulu ke posisi $1,16 \% \mathrm{dk} / \mathrm{k}$ yang dicapai dengan waktu 11,7 jam dengan posisi CR $51 \%, 52 \%, 53 \%$ dan $54 \%$.

Daya reaktor yang bisa dihasilkan dari proses penarikan CR setelah scram, sampai dengan penarikan $51 \%$ belum mampu mencapai daya lebih dari $30 \%$, seperti yang ditunjukkan pada Gambar 7 . Posisi CR yang dapat menghasilkan daya di atas $30 \%$ daya nominal RDE adalah CR dengan posisi mulai $52 \%$ seperti yang telihat pada Gambar 8.

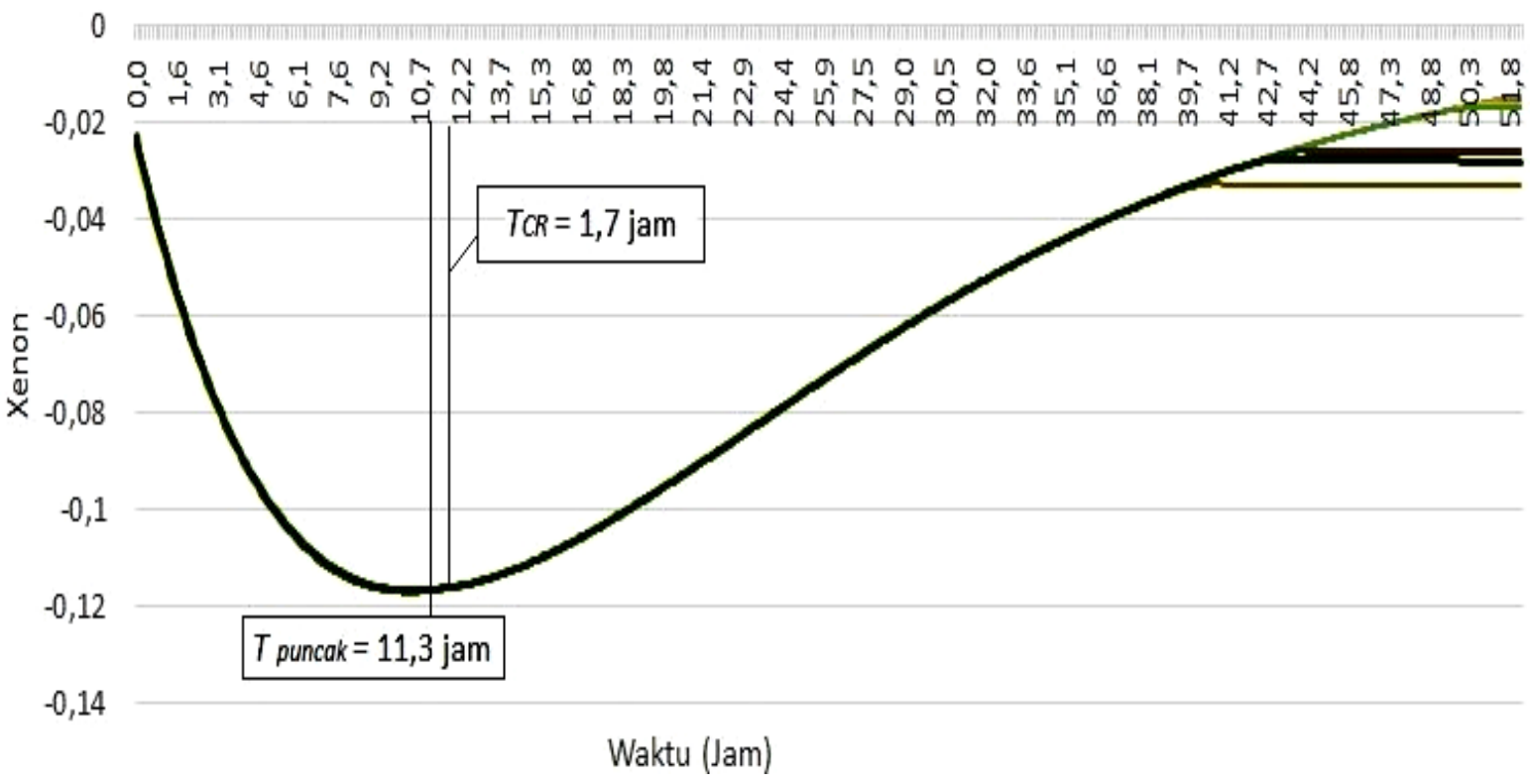

Gambar 6. Perubahan Xenon akibat SCRAM pada RDE.

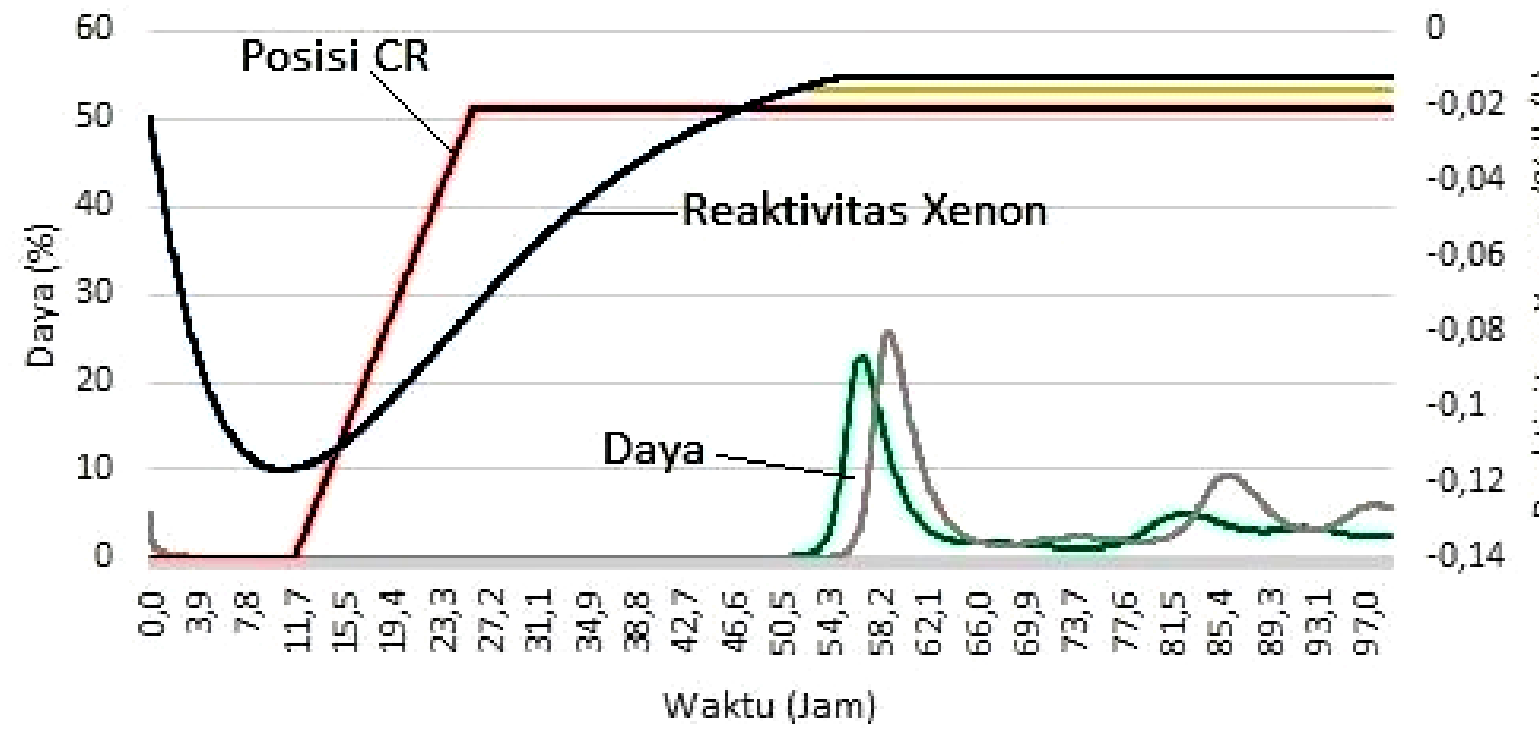

Gambar 7. Kenaikan daya dengan posisi CR $51 \%$. 
Jurnal Iptek Nuklir Ganendra

Ganendra Journal of Nuclear Science and Technology

Vol. 19, No. 2, Juli 2016 : 83-93

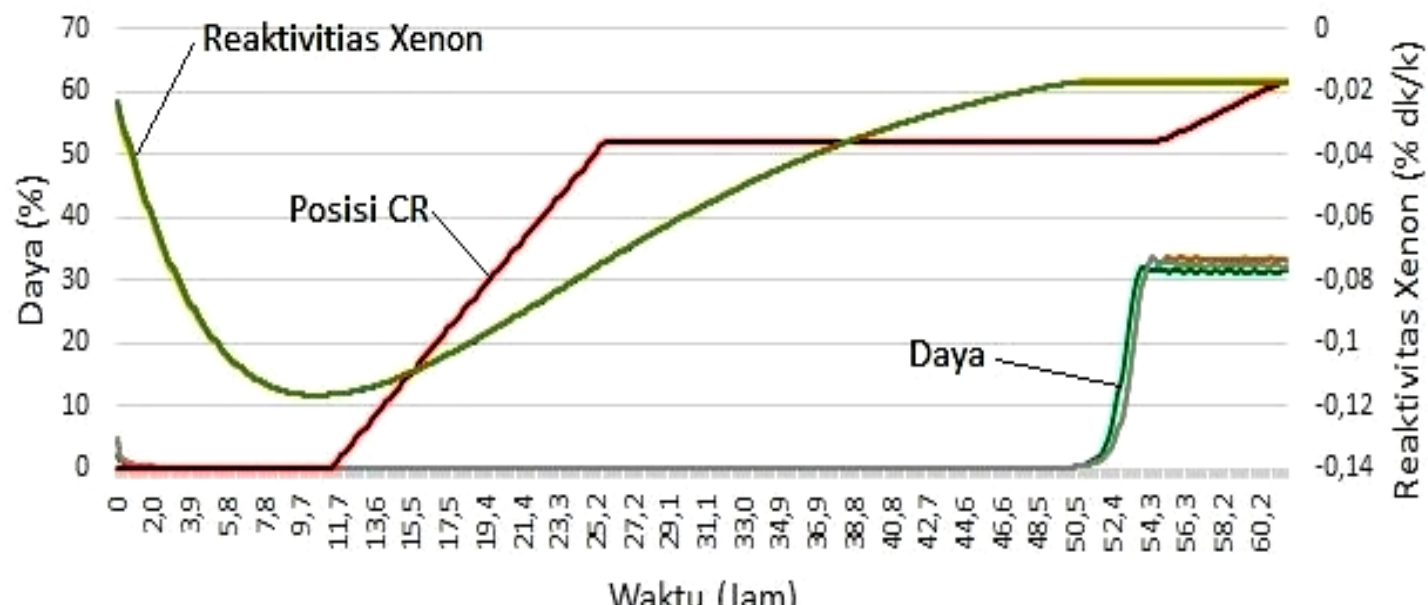

Gambar 8. Kenaikan daya dengan posisi CR 52\%.

\section{Perubahan Fluks Neutron}

Pada simulasi ini dilakukan penaikan CR setelah 11,7 jam dari reaktor scram yaitu setelah xenon melewati puncaknya seperti terlihat pada Gambar 8, di mana CR naik sampai posisi $52 \%$ dalam waktu 12,5 jam. Akibat kenaikan batang batang kendali (CR) tersebut terjadi perubahan fluks neutron seperti pola yang disajikan pada Gambar 9. Terlihat bahwa fluks neutron akan naik dengan cepat sampai tingkat maksimum jika posisi CR $54 \%$ yaitu dengan waktu 41 jam dan pada posisi CR 51\% perubahan kenaikan fluks neutron terjadi sangat lambat.

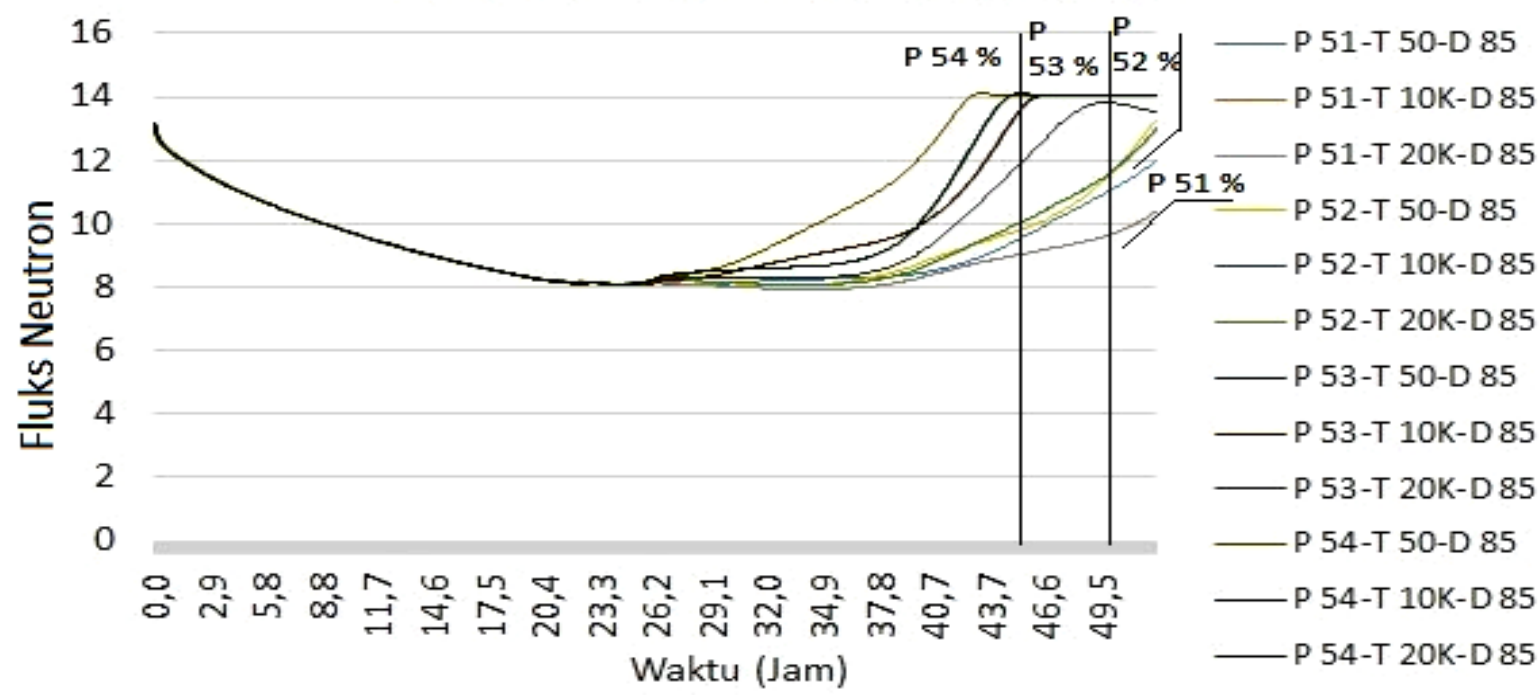

Gambar 9. Perubahan fluks neutron akibat reaktor scram dan setelah kenaikan CR.

\section{Perubahan Suhu Pendingin Reaktor}

Suhu pendingin reaktor terkait dengan kenaikan CR ternyata dengan posisi CR $51 \%$ hingga CR $54 \%$ menimbulkan kenaikan suhu pendingin RDE yang masih dalam batasan-batasan operasi yaitu suhu inlet maupun outlet masih di bawah $900{ }^{\circ} \mathrm{C}$ pada sistem combine cycle [2]. Perubahan suhu pendingin inlet dan outlet teras RDE masing-masing ditunjukkan pada Gambar 10 dan Gambar 11. Terlihat bahwa suhu inlet yang dihasilkan setelah RDE superkritis (Gambar 10) khususnya untuk posisi CR 54\% dan CR 53\% menunjukkan bahwa reaktor masih aman dan demikian juga untuk CR 52\% dan CR 51\%. Kenaikan suhu untuk posisi CR 52\% dan CR 51\% lebih lama karena sesuai Gambar 9 untuk posisi tersebut fluks neutron baru saja mencapai puncaknya (CR $52 \%)$ sehingga suhu baru mulai meningkat. Kemudian untuk CR 51\% dengan suhu tersebut sesuai Gambar 4.10 tidak mampu untuk menghasilkan daya di atas $30 \%$. Perubahan kenaikan suhu tersebut juga masih berada di bawah kenaikan suhu reaktor jika terjadi kondisi transient without scram dengan sebuah CR $[13,14]$. 


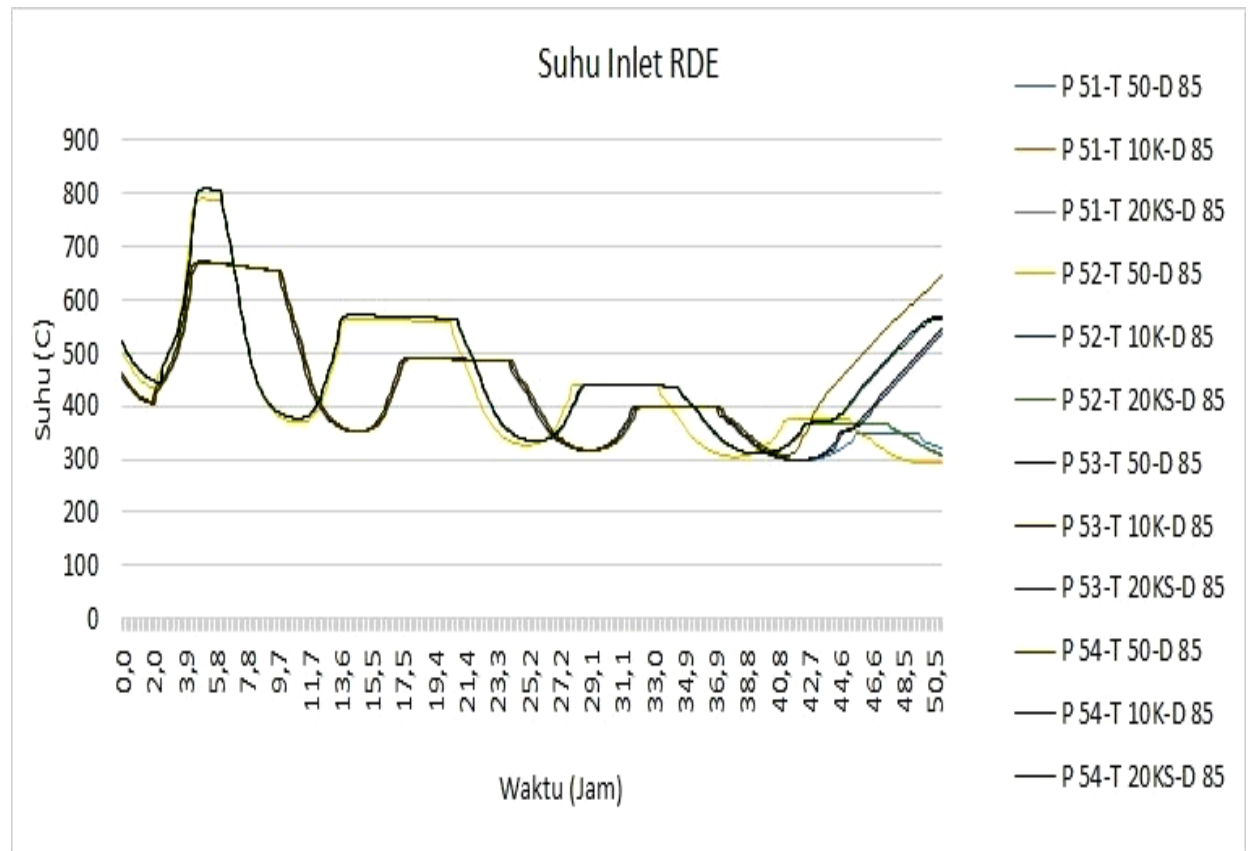

Gambar 10. Perubahan suhu pendingin inlet teras RDE sebagai fungsi waktu dan kenaikan CR $51 \%$ s/d $54 \%$.

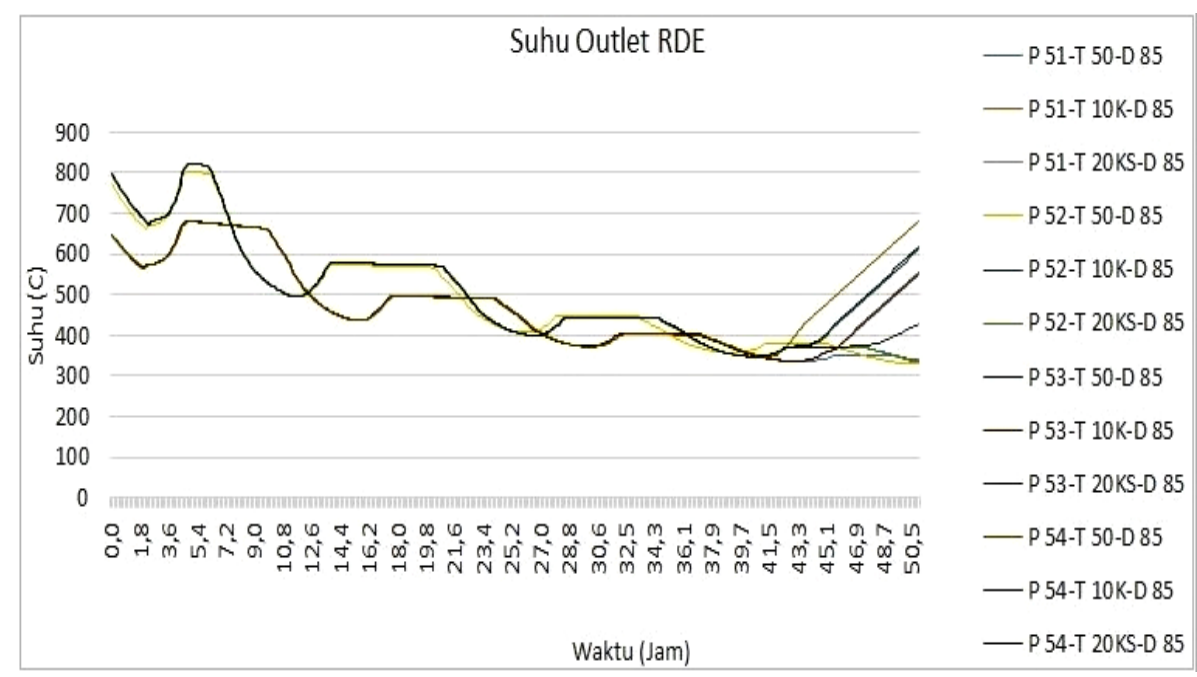

Gambar 11. Perubahan suhu pendingin outlet teras RDE sebagai fungsi waktu dan kenaikan CR $51 \%$ s/d $54 \%$.

Dalam perkembangannya ada dua fase mode operasi HTR-10, pada fase pertama reaktor dioperasikan seperti tersebut di atas yaitu dengan suhu pendingin outlet dari reaktor $700{ }^{\circ} \mathrm{C}$, suhu inlet ke reaktor $250{ }^{\circ} \mathrm{C}$. Sistem sekundernya meliputi sebuah turbin uap untuk menggerakkan generator listrik. Generator uap (SG) akan menghasilkan suhu uap $440{ }^{\circ} \mathrm{C}$ dan tekanan $4 \mathrm{Mpa}$. Sedangkan pada fase kedua HTR-10 dioperasikan pada suhu outlet teras $900^{\circ} \mathrm{C}$ dan inlet $300^{\circ} \mathrm{C}$. Pembangkitan listriknya dengan combine cycle menggunakan sebuah turbin gas (GT) dan sebuah turbin uap (ST). Intermediate heat exchanger (IHX), dengan daya termal $5 \mathrm{MW}$ disediakan sebagai penyedia gas nitrogen suhu tinggi $850{ }^{\circ} \mathrm{C}$ untuk siklus GT, sedangkan $5 \mathrm{MW}$ sisanya digunakan untuk siklus ST di mana SG memproduksi uap pada suhu $435{ }^{\circ} \mathrm{C}[2,13]$. Diagram skematik steam turbine/gas turbine combined cycle HTR-10 dilukiskan pada Gambar 12. Analisis simulasi penarikan batang kendali paska reaktor scram ini jika merujuk pada batas kondisi operasi (BKO) dengan mode operasi fase pertama menunjukkan suhu inlet dan outlet pendingin sedikit berada di atas BKO. Sedangkan jika merujuk pada mode operasi fase kedua yaitu dengan sistem combine cycle, menunjukkan hasil masih di bawah BKO sehingga bisa disimpulkan reaktor aman. Secara umum penarikan batang kendali untuk melanjutkan operasi paska scram 
pada RDE tidak akan melampaui BKO dan tidak melampaui suhu pendingin jika satu batang kendali ditarik penuh dari reflektor, yaitu sampai dengan suhu outlet $850^{\circ} \mathrm{C}$ reaktor masih aman $[10,13,15]$.

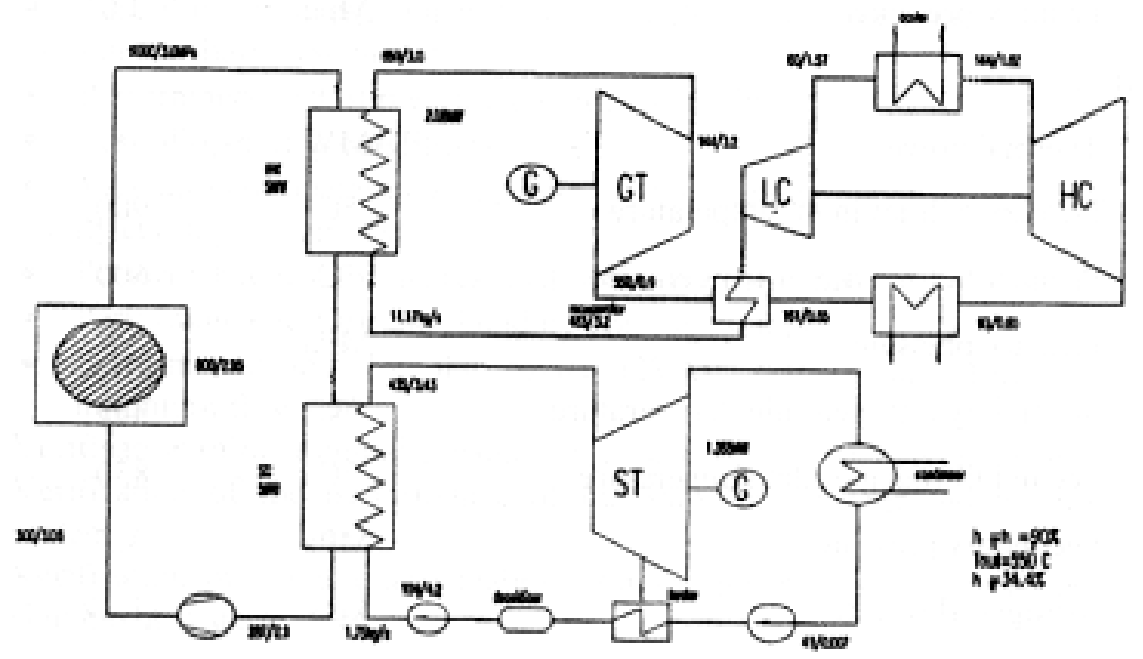

Gambar 12. Diagram skematik steam turbine/gas turbine combined cycle HTR-10 [2].

Hasil analisis simulasi pengaturan posisi batang-batang kendali untuk melanjutkan operasi RDE paska scram ini merupakan bagian dari simulator hybrid berbasis reaktor Kartini, sehingga dapat ditayangkan pada layar komputer di ruang simulator [4]. Dengan demikian diharapkan dengan metode penyajian dengan penayangan hasil simulasi pengendalian RDE akan lebih menambah apresiasi peserta pelatihan, hal ini sesuai dengan hasil penelitian Vahid Motamedi [12].

\section{KESIMPULAN}

Berdasarkan hasil analisis simulasi pengaturan posisi batang-batang kendali untuk melanjutkan operasi RDE paska scram setelah beroperasi pada beberapa periode waktu tertentu, dapat disimpulkan bahwa RDE dapat dioperasikan kembali dengan mengatur posisi batang-batang kendali (CR) minimal ditarik $52 \%$ naik. Hal tersebut menunjukkan bahwa dengan posisi CR naik $52 \%$ sudah bisa menghasilkan kondisi kritis dan mampu mengatasi reaktivitas negatif peracunan xenon maupun suhu. Suhu reaktor setelah posisi batang kendali dinaikkan s/d $54 \%$ masih berada pada batasan yang ditentukan untuk sistem combine cycle $\left(90{ }^{\circ} \mathrm{C}\right)$ yang berarti reaktor aman.

\section{UCAPAN TERIMA KASIH}

Penulis mengucapkan terimakasih kepada Kepala PSTA Dr. Susilo Widodo yang telah memberikan motivasi dan dukungan dalam riset ini berupa pendanaan dalam DIPA PSTA. Ucapan terimakasih kami sampaikan pula kepada seluruh staf Bidang Reaktor PSTA atas diskusi dan saran-sarannya yang berharga untuk perbaikan makalah ini.

\section{DAFTAR PUSTAKA}

1. Anonim, "User Requirement Document - Reaktor Daya Eksperimental ", BATAN (2014):10-11

2. IAEA-TECDOC-1382, "Evaluation of High Temperature Gas-Cooled Reactor Performance: Beenchmark Analysis Related to Initial Testing of the HTTR and HTR-10", IAEA, Vienna, Austria, November (2003): 2-4

3. Syarip, "Litbang Simulator Hibrid Berbasis Reaktor Kartini Untuk Pelatihan Pengendalian RDE", Dok. Teknik, PSTA BATAN, (2015): 3-4

4. IAEA-TECDOC-1694, "Evaluation of High Temperature Gas Cooled Reactor Performance: Benchmark Analysis Rrelated to the PBMR-400, PBMM, GT-MHR, HTR-10 and the ASTRA Critical Facility", IAEA, Vienna, Austria, (2013): 110-111. 
5. Sui Zhe, Sun Jun, Wei Chunlin, Ma Yuanle, "The Engineering Simulation System for HTR-PM", Nuclear Engineering and Design, 271 (2014): 479-486

6. Takamatsu, et, al. "High Temperature Continuous Operation int HTTR (HP-11)-Summary of the Test Result in the High Temperature Operation Mode", JAEA Tech 2010-038, Oarai-machi: JAEA, (2010): 4-5

7. Takeda, et. al. "Safety Shutdown of the High Temperature Engineering Test Reactor during Loss of Off-site Electric Power Simulation Test", Oarai-Machi:Taylor \& Francis. (2002): 2-4

8. Tochio, et. al. "Operating Experience since Rise to Power Test in High Temperature Engineering Test Reactor (HTTR)", JAEA Technology, Shirakata Shirane: JAEA. (2007): 2-3

9. F. Chen, Y. Dong, and Z. Zhang, "Temperature Response of the HTR-10 during the Power Ascension Test", Science and Technology of Nuclear Installations, (2015):13. Article ID 302648, Hindawi Publishing Corporation. http://dx.doi.org/10.1155/2015/302648, diakses Juni (2016).

10. F. Chen, Y. Dong, Y. Zheng, L. SHI \& Z. Zhang, "Benchmark Calculation for the Steady-State Temperature Distribution of the HTR-10 Under Full-Power Operation", Journal of Nuclear Science and Technology, 46.6, (2009): 572-580

11. Manual of PCTRAN HTR Simulator Software for PC, Micro-Simulation Technology 10 Navajo Court Montville, New Jersey 07045 USA, (2015): 3-4

12. V. Motamedi, "Computer Presentation Programs and Teaching Research Methodologies". Journal of Education and Learning. 9.2 (2015): 111-116.

13. M. Langa, Y. Dongba, "The ATWS Analysis of One Control Rod Withdraw Out of the HTR-10GT Core in Addition With Bypass Valve Failure". Nuclear Engineering and Design, 271 (2014): 459-464.

14. Z. Yangping, et, al, "Thermal-hydraulic Simulation of the Primary Loop of the HTR". Nuclear Safety and Simulation, 1.4 (2010): 23.

15. Jun et al., "The Benchmark Calculations of the GAMMA+ Code with the HTR-10 Safety Demonstration Experiments", Nuclear Engineering and Technology, 41.3 (2009): 317. 